\title{
Students' Perspectives: E-Learning During Covid-19 Pandemic
}

\author{
Melgis Dilkawaty Pratama ${ }^{1}$, Nelvia Ibrahim ${ }^{2}$ \\ Universitas Islam Negeri Sultan Syarif Kasim Riau ${ }^{1}$, Universitas Islam Negeri Sultan \\ Syarif Kasim Riau ${ }^{2}$ \\ $\underline{\text { melgis.dilkawaty.pratama@uin-suska.ac.id }}^{1}$, nelvia.ibrahim@uin-suska.ac.id $^{2}$
}

\begin{abstract}
The implementation of e-learning during Covid-19 Pandemic raises pro and cons particularly among the university students such as internet access, budget and quota, as well as overload tasks. However, others think e-learning is the appropriate one to establish the learning process during physical distance regulation as the prevention of Covid-19. This research aims to describe the student perspectives on the implementation of e-learning during Covid-19 Pandemic. The design of this study was quantitative research. 189 university students in Riau, Indonesia participated by snowball sampling technique. The research collected data by employing a questionnaire in the Google form and sharing it through What Sapp. The data was analyzed by the descriptive statistics. The research revealed the implementation of e-learning among the university students was not optimal. The synchronous and asynchronous as the interaction schemes were established separately. Only $10.58 \%$ students had experienced both schemes. Furthermore, internet access, and internet quota and budget were the major inhibiting factors. This research expects the educators and stakeholders evaluating the implementation of e-learning and provides comprehensive trainings for educators on e-learning.
\end{abstract}

Keywords: e-learning, synchronous, asynchronous

\section{A. Introduction}

E-learning has become a paramount aspect in the provision of education due to the Covid-19 outbreak. All learning process must use online mode. Elearning provides a platform for both students and teacher to facilitate their learning in more flexible ways. Teacher can deliver their materials, quizzes, written examination, and discussion to students both synchronous and asynchronous. Students, in addition, should adjust with this learning shift. However, many of them experience obstacles in e-learning such as internet access (Almaiah, et al, 2020; Wan
Hassan, et al, 2020), internet data packages (Aini, Q., Putra, P., Budiarto, M., Rahardha, U., 2020; Al Balas, et al, 2020; Farooq, et al, 2020), and overload task (Ranastu-Avalos and Siiman, 2020; Zulkifli, et al, 2020; Adedoyin, O., Soykan E., 2020).

Many studies generated mixed results for e-learning and learning improvement (Cappel \& Hayen, 2004; Ruiz JG, Mintzer MJ, Leipzig RM 2006 ; Cook D, et al, 2008). In general, e-learning is considered less effective to acquire knowledge, skills, and good behaviour (Al-Shorbaji N, Atun R, Car J, Majeed 
A, 2015; Fletcher J., 2007). Students should deal with challenges of selfregulation in using e-learning (Aini, Q., Putra, P., Budiarto, M., Rahardha, U., 2020). In contrast, e-learning has positively improved retention of learning (Parry, Larsen, Marwood, et al, 2007; Hammarlund, Nilsson, Gummesson, 2015; Morton, Saleh, Smith, et al, 2016). However, there have been limited studies on e-learning in the context of Covid-19 Pandemic. Therefore, to find out better practices how to teach and learn by using e-learning during Covid19 Pandemics, understanding all learning components including students is important. Analyzing students' perspectives on the implementation of elearning can be a counterbalance between teacher and student practices and results a proper evaluation.

\section{B. Literature Review}

E-learning is education provision through various ICT media including instructing, teaching and learning (Koohang and Harman, 2005). Similarly, Gotchal (2000) explains e-learning is a distance learning in which teacher delivers teaching materials to students by using online video presentation and connected by network and computer. Furthermore, Grandbastian, Ouhbahsi, and Claes (2003) defined e-learning as a process which includes basic inputs (knowledge, experience, and curriculum) and suppliers (teachers, trainers, technicians, and other specialists in the field), then transformed (external factors such human and material resources, performance, and progress) into outputs (training sessions, evaluation, analysis, and other information) to the students. In addition, flexibility of time and place are also involved in the process of e-learning (Almosa, 2002; Smedley, 2010; Jose \& Christoper, 2018), and oriented to students' needs (Marc, 2002).
However, e-learning also raises some issues such as extra cost and time (Collins, et al, 1997), class limitations, boredom in learning, and limited interactions (Rabiman, Nurtanto, and Kholifah, 2020). According to Ruiz et al. (2006), there are three components of elearning: (a) content development; (b) content management; (c) content delivery (synchronous and asynchronous). Adversely, e-learning is merely viewed as technology tools rather than pedagogy (Higher Education Funding Council for England, 2009). Many studies revealed that the implementation of e-learning like as ereading (Nichani, 2002). In addition, many others believed e-learning as digital page turning, but it offers nothing (Masie, 2001).

In e-learning, there are two interaction schemes: synchronous and asynchronous mode. Synchronous mode requires real time teaching (Abubakar et al., 2017: 218), and supported by live streaming video and chat (Hranstinski, S, 2007) to interact between teachers and students in sharing knowledge or ideas. In contrast, asynchronous does not need real time interaction such as email and discussion forum (Almosa \& Almubarak, 2005) in which teacher can share message or instructional materials, and students can download it at any times (Hrastinski, 2007). Both synchronous and asynchronous can strongly affect students' comprehension on the course (Nganji, 2018). According to Offer, Lev, and Bezalel (2008), asynchronous mode can affect students' performance in which there is no students-teacher dialogue. In contrast, synchronous mode provides live academic discussion to assist students understand the course content (Nganji, 2018) and a sense of community (Boelens, De Wever, and Voet, 2017). However, the availability of 
both synchronous and asynchronous can enrich the student interaction and opportunity to ask and respond in the learning process. Fisher, M., Coleman, B., Sparks, P., Plett, C., 46)

To provide an effective e-learning, teachers should establish meaningful learning environment. In this environment, students learn best socially through collaboration in which the knowledge is provided contextually by the community. An ideal learning environment is a place for students to gain identity and confidence. Students can get the knowledge by actively participating in the practice of community and connecting the previous and new knowledge (IRL, 1990). According to Arias (1999), to get supporting informed participation requires process that integrated individual and group knowledge through collaborative constructions. Furthermore, collaborative construction can be provided through cognitive flexibility. The cognitive flexibility can present both cognitive and personal participation and reduce rigidity of thought and action. In addition, cognitive flexibility can provide "openness-based "flexibility in which it can access for adaptive knowledge application, and transfer knowledge to new situation. So, collaborative construction and cognitive flexibility are the main features in establishing meaningful learning environment in e-learning.

According to Adedoyin, O., and Soykan E., (2020), there are several factors influencing the implementation of elearning include technology, socioeconomic, human and pets intrusions, digital competence, assessment supervision, heavy workload, compatibility, opportunities, research innovation, and technological innovation. In addition, Brand and
Dousay (2015) explain the absence of the thorough plan either in the design or instruction can be an acceptance by the users in the application of online learning. This rejection believes the online learning as an emergency remote teaching rather than the alternative ways during this pandemic (Bozkurt \& Sharma, 2020; Hodges et al., 2020; Vlachopuolos, 2020). Furthermore, Feldman (n.d) noted some negative impacts of e-learning such as (1) students anxiety on their academic performance, (2) biassed assessment, (3) teacher unready to provide highquality instruction remotely, and (4) racial, social and resource differences. According to Bonk and Dennen (1999), attrition rates and low participation are frequent complain by teachers in elearning. Besides, lack of training, less information how to engage students in online learning, and not to know how to embed effective pedagogy and weak in utilizing the technology are challenges facing by the teachers (Dennen and Bonk, 2007).

\section{Research Method}

This research was quantitative with a survey design. There were 189 university students in Riau, Indonesia participated in this research by employing snowball sampling technique. This sampling technique was used because of limitation in accessing samples during Covid-19 Pandemics. There were physical distance regulation by government and study from home by university's regulation enabling the researchers to gather data by other sampling techniques. This research was conducted in June 2020 for a month in which the university students had already accomplished their semester by full online learning for the first time . The data was collected by sharing a questionnaire in the google form through 
WhatsApp groups and analyzed by the descriptive statistics.

\section{Results and Discussion}

This research figured out that since Covid-19 pandemic, the students used elearning every day $(91 \%)$ as seen in table 1.

Table 1 Frequency of using E-learning

\begin{tabular}{clrr}
\hline No & \multicolumn{1}{c}{ Response } & Frequency & \multicolumn{2}{c}{ Percentage } \\
\hline 1 & Everyday & 172 & 91.01 \\
2 & Every week & 7 & 3.70 \\
3 & Every two weeks & 4 & 2.12 \\
4 & Every month & 1 & 0.53 \\
& Every couple of & & \\
5 & months & 4 & 2.12 \\
6 & Every once a year & 1 & 0.53 \\
\hline & Total & 189 &
\end{tabular}

1. Interaction Scheme

For interaction scheme, students used synchronous mode $(43.92 \%)$ by using Whatsapp, Zoom, and Google Meet. Other students used asynchronous mode
(45.51\%) by using Edmodo, Google Classroom, . There were 10.58 used both synchronous and synchronous mode $(10.58 \%)$ by using combination of some apps of e-learning as seen in table 2 .

Table 2 Forms of E-Learning

\begin{tabular}{clrr}
\hline No & Forms of E-Learning & Frequency & Percentage \\
\hline 1 & Edmodo & 3 & 1.59 \\
2 & Google Classroom & 80 & 42.33 \\
3 & Whatsapp & 77 & 40.74 \\
4 & Combination of Some Apps & 20 & 10.58 \\
5 & Youtube & 3 & 1.59 \\
6 & Zoom & 4 & 2.12 \\
7 & Google Meet & 2 & 1.06 \\
\hline & Total & 189 & \\
\hline
\end{tabular}

Based on table 2 , only $10.58 \%$ students had experienced both synchronous and asynchronous mode which resulted in balancing both cognitive and personal participation. Meanwhile, $89.42 \%$ students had not experienced both thoroughly in which $43.92 \%$ students received personal participation and $45.51 \%$ received cognitive participation. Based on data, majority of students were not provided optimal approaches in encountering their learning styles and needs.

Table 3 Form of Activities

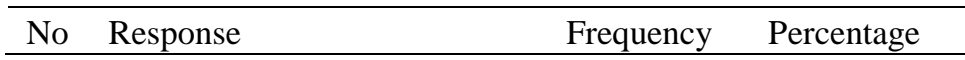

In addition, to support data in table 2, table 3 showed that there were 7 activities conducted in e-learning such as discussion (53.97\%), exercise or quiz (17.46\%), summary (15.87\%), combined activities (4.23\%), task $(2.65 \%)$, reading books or articles $(2.65 \%)$, watching videos $(2.65 \%)$, and essay $(0.53 \%)$. 


\begin{tabular}{llrr}
1 & Discussion & 102 & 53.97 \\
2 & Task & 5 & 2.65 \\
3 & Exercise or Quiz & 33 & 17.46 \\
4 & Combination & 8 & 4.23 \\
5 & Read Books or Articles & 5 & 2.65 \\
6 & Summary & 30 & 15.87 \\
& Watching Videos & 5 & 2.65 \\
& Essay & 1 & 0.53 \\
\hline & Total & 189 & \\
\hline
\end{tabular}

From table 3 , it strengthen that one mainly synchronous activity was discussion 53.97\%. Meanwhile, others activities $(41.81 \%)$ such as exercise or quiz $(17.46 \%)$, summary (15.87\%), task $(2.65 \%)$, reading books or articles $(2.65 \%)$, watching videos $(2.65 \%)$, and

essay (0.53\%) were included as asynchronous activities. Only $2.65 \%$ activities promoted combination of synchronous and asynchronous mode.

2. Students' self-esteem in using elearning,

Table 4 The Competency

\begin{tabular}{rlrr}
\hline No & Response & Frequency & Percentage \\
\hline & $\begin{array}{l}\text { Advanced } \\
\text { (Applied }\end{array}$ & 17 & 8.99 \\
1 & $\begin{array}{l}\text { Theory) } \\
\text { Intermediate } \\
\text { (Practical }\end{array}$ & & \\
2 & $\begin{array}{l}\text { Application) } \\
\text { Novice (Limited } \\
3\end{array}$ & 130 & 68.78 \\
& $\begin{array}{l}\text { Experiences) } \\
\text { Fundamental }\end{array}$ & 39 & 20.63 \\
& $\begin{array}{l}\text { Awareness } \\
\text { (Basic }\end{array}$ & & \\
4 & Knowledge) & & \\
5 & Not Applicable & 3 & \\
\hline & Total & 0 & 0 \\
\hline
\end{tabular}

Based on table 4, majority of students (77.77\%) perceived they have good competence in using e-learning in which $8.99 \%$ students were advanced (applied theory) and $68.78 \%$ students were intermediate (practical application). Meanwhile, only $1.59 \%$ students perceived that they were novice (basic knowledge) in using elearning.
3. Students' Motivation on E-Learning

Table 5 displayed the students' feeling on e-learning. Majority of students $(66.67 \%)$ had negative response on this item, in which students felt less excited $(55.03 \%)$, not excited $(9.52 \%)$, and very not excited (2.12\%). Meanwhile, students felt excited $(32.80 \%)$ and very excited $(0.52 \%)$.

Table 5 Feeling on E-Learning

\begin{tabular}{cccc}
\hline No & Response & Frequency & Percentage \\
\hline 1 & Less Excited & 104 & 55.03 \\
2 & Excited & 62 & 32.80 \\
3 & Very not Excited & 4 & 2.12 \\
4 & Not Excited & 18 & 9.52 \\
5 & Very Excited & 1 & 0.53 \\
\hline \multicolumn{5}{c}{ Total } & 189 \\
\hline
\end{tabular}


Table 6 showed that the interaction established during learning process through e-learning. Students considered the interaction occurred during learning was less interactive $(46.52 \%)$ and not interactive (5.88\%). Meanwhile, students thought the interaction was interactive $(43.85 \%)$ and very interactive (3.74\%).

Table 4 Teaching Interaction

\begin{tabular}{rlrr}
\hline No & Response & Frequency & Percentage \\
\hline 1 & Interactive & 82 & 43,85 \\
2 & Less Interactive & 87 & 46,52 \\
3 & Very Interactive & 7 & 3,74 \\
4 & not Interactive & 11 & 5,88 \\
\hline & Total & 187 & \\
\hline
\end{tabular}

In table 7 , it showed teaching activities were less varied $(30.69 \%)$, unvaried $(4.76 \%)$, very unvaried $(2.12 \%)$.
Surprisingly, $49.21 \%$ students thought teaching styles varied and $13.23 \%$ students thought very unvaried.

Table 5 Teaching Activities

\begin{tabular}{clrr}
\hline No & Response & Frequency & Percentage \\
\hline 1 & Less Varied & 58 & 30,69 \\
2 & Very Varied & 25 & 13,23 \\
3 & Very unvaried & 4 & 2,12 \\
4 & Not Varied & 9 & 4,76 \\
5 & Varied & 93 & 49,21 \\
\hline & Total & 189 & \\
\hline
\end{tabular}

4. The implementation of E-Learning

Table 8 The Use of E-Learning

\begin{tabular}{cccc}
\hline No & Response & Frequency & Percentage \\
\hline 1 & Very Effective & 2 & 1.06 \\
2 & Effective & 35 & 18.52 \\
3 & Less Effective & 130 & 68.78 \\
4 & Not Effective & 15 & 7.94 \\
& Very Not & & 3.70 \\
5 & Effective & 7 & \\
\hline \multicolumn{5}{c}{ Total } & 189 & \\
\hline
\end{tabular}

In table $8,80.42 \%$ students had bad impression on the use of e-learning in whih students thought it was less effective (68.78\%), not effective $(7.94 \%)$, and very not effective (3.70\%). Meanwhile, students thought the use of e-learning was effective $(18.52 \%)$ and very effective $(1.06 \%)$.

The implementation of e-learning, based on students' perspectives, was less effective. It was influenced by some inhibiting factors such as unavailability of facilities (61.29\%), incomprehensible teaching material (27.96\%), less students' ability in using e-learning (4.84\%), less teaching ability in using e-learning $(3.76 \%)$, less teacher explanation $(1.08 \%)$, unrelax teaching atmosphere $(0.54 \%)$, and inappropriate teaching schedule $(0.5 \%)$ as seen in table 5 . 
Table 9 Inhibiting Factors

\begin{tabular}{clrr}
\hline No & Response & Frequency & Percentage \\
\hline 1 & Unavailability of Facilities & 114 & 61,29 \\
2 & Incomprehensible Teaching Material & 52 & 27,96 \\
3 & Unrelax teaching atmosphere & 1 & 0,54 \\
4 & Less Teacher Explanation & 2 & 1,08 \\
5 & Inappropriate teaching schedule & 1 & 0,54 \\
6 & Less Teaching Ability in Using E-Learning & 7 & 3,76 \\
7 & Less Student Ability in Using E-Learning & 9 & 4,84 \\
\hline & Total & 186 &
\end{tabular}

In addition, to specify the unavailability of facilities which challenges students in using e-learning, students mentioned some obstacles in suing e-learning such as internet access (58.70\%), internet package $(33.70 \%)$, electricity $(4.35 \%)$, headphone $(1.63 \%)$, and laptop $(1.63 \%)$ as seen in table 6 .

Table 10 Obstacles in Using E-Learning

\begin{tabular}{clrr}
\hline No & Response & Frequency & Percentage \\
\hline 1 & Internet Access & 108 & 58,70 \\
2 & Hand phone & 3 & 1,63 \\
3 & Internet Package & 62 & 33,70 \\
4 & Laptop & 3 & 1,63 \\
5 & Electricity & 8 & 4,35 \\
\hline & Total & 184 & \\
\hline
\end{tabular}

To strengthen the students' perspectives in using e-learning. Students were asked whether they want to use e-learning after Covid-19 pandemic. Students' response were no $(67.73 \%)$ and yes $(32.28 \%)$ as seen in table 7 .

Table 11 Recommendation to Use E-Learning after Covid-19

\begin{tabular}{lllrr}
\hline No & Response & Frequency & \multicolumn{2}{c}{ Percentage } \\
\hline & 1 & No & 128 & 67,72487 \\
& 2 & Yes & 61 & 32,27513 \\
\hline & Total & 189 & \\
\hline
\end{tabular}

In addition, students were also asked whether they want to recommend elearning to others. Consistently,

Table

\begin{tabular}{|c|c|c|c|}
\hline No & Response & Frequency & Percentage \\
\hline 1 & No & 101 & 53,44 \\
\hline \multirow[t]{2}{*}{2} & Yes & 88 & 46,56 \\
\hline & Total & 189 & \\
\hline
\end{tabular}

students' response were no (54.44\%) and yes $(46.56 \%)$

\section{E. Conclusion}


The research concluded that the implementation of e-learning among the university students was not optimal. Most of the e-learning process used asynchronous mode by emphasizing more on cognitive participation, not personal participation. In addition, majority of e-learning design model used class type. The application of elearning did not promote learning anlytics in which the learning process was less interactive. Furthermore, internet access, and internet quota and budget were the major inhibiting factors. This research expects the educators and stakeholders evaluating the implementation of e-learning and provides comprehensive trainings for educators on e-learning.

\section{References}

Abu Bakar, M., et al,. 2017. "Elearning: A tool for Enhancing Teaching and Learning in Education Institutes". The International Journal of Computer Science and Information Technologies. Vol. 8 (2), 2017, 217-221. From http://www.researchgate.net/publi cation/321304469 Retrieved on $10^{\text {th }}$ June, 2020.

Aini, Q., Putra, P., Budiarto, M., Rahardha U. 2020. "Exploring Elearning Challenges during the Global Covid-19 Pandemic : A Review". Journal of Information System. Volume 16. Issue 2. Pp. 57-65

Al-Balas, M., Al-Balas, H. I., Jaber, H. M., Obeidat, K., Al-Balas, H., Aborajooh, E. A., Al-Taher, R.,and Al-Balas, B. 2020. "Distance Learning in Clinical Medical Education amid COVID19 Pandemic in Jordan: Current Situation, Challenges, and Perspectives"
Algahtani, A.F. 2011. Evaluating the Effectiveness of the E-Learning Experience in Some Universities in Saudi Arabia from Male Students' Perception. Durham Theses. Durham University. From https://www.semanticscholar.org Retrieved on $10^{\text {th }}$ June, 2020.

Almosa, A. 2002. Use of Computer in Education ( $2^{\text {nd }}$ ed). Riyadh: Future Education Library.

Al-Shorbaji N, Atun R, Car J, Majeed A. 2015. Wheeler E. E-learning for undergraduate health professional education: a systematic review information of health workforce development. Geneva: Imperial College/WHO.

Arkaful, V and Abaidoo, N. 2014. "The Role of E-Learning, The Advantages and Disadvantages of its Adoption in Higher Education". International Journal of Education and Research. Vol (2) No.12. From https://www.ijern.com>2014pdf Retrieved on $10^{\text {th }}$ June, 2020

Branch, R. M., \& Dousay, T. A. (2015). Survey of instructional development models (5th Ed.). Association for Educational Communications and Technology. https://aect.org/docs/SurveyofInst ructionalDesignModels.pdf?pdf= SurveyofInstructionalDesignMod els

Cappel JJ, Hayen RL. 2004. Evaluating e-learning: a case study. J Comput Inf Syst. 44:49-56.

Collins, J., Hammond, M. and Wellington, J. 1997. Teaching and Learning with Multi Media. London: Routledge.

Cook D, Levinson A, Garside S, Dupras D, Erwin P, Montori V. 2008. Internet-based learning in the 
health professions: a metaanalysis. JAMA.300:1181-96.

Dennen and Bonk. 2007. "We will the

Light on for You: Keeping

Learners Motivated in Online

Courses." Flexible Learning in an

Information Society. Badrul H

Khan (eds). London: Information

Science Publishing (Idea Group, Inc).

Dublin, L. 2003. Nine E-Learning Myths. The E-Learning Develop Journal. From http://www.elearningguild.com Retrieved on $9^{\text {th }}$ June, 2020.

Feldman, J. (n.d.). "To Grade or Not to Grade?".

https://filecabinetdublin.eschoolvi ew.com/6D88CF03-93EE-

4E59B267B73AA2456ED7/ToGr adeorNottoGradearticle.pdf

Fisher, M., Coleman, B., Sparks, P., Plett, C. 2007. "Designing Community Learning in WebBased Environments". Flexible Learning in an Information Society. Khan, Badrul H (eds). London: Informaton Science Publishing (Idea Group Inc)

Fletcher J. 2007. Clinical epidemiology notes. What is heterogeneity and is it important? BMJ.334:94-6.

Gotschall, M. 2000. E-Learning Strategies for Executive Education and Corporate Training. Fortune 141 (10): 5-59. From https://www.ijedict.dec.vwi.edu Retrieved on $9^{\text {th }}$ June, 2020.

Hammarlund CS, Nilsson MH, Gummesson C. 2015. "External and Internal Factors Influencing Self-Directed Online Learning of Physiotherapy Undergraduate Students in Sweden: A Qualitative Study". J Educ Eval Health Prof. 12:33.
Hrastinski, S. 2008. Asynchronous and Synchronous E-Learning. Educause Quartely. No.4. 2008. From https://er.educause.edu/articles/20 08//11/. Retrieved on $10^{\text {th }}$ June 2020.

Higher Education Funding Council for England. 2009. "Enhancing Learning and Teaching through the Use of Technology: A Revised Approach to HEFCE's Strategy for E-Learning". http://webarchive.nationalarchives .gov.uk/20100202100434/http://w ww.hefce.ac.uk/pubs/hefce/2009/ 09_12/09_12.pdf.Accessed 31 Oct 2019.

Institute for Research and Learning. 2001. "IRL Perspectives and Principles of Learning: Challenging Fundamental Assumption (pamphlet)". Menlo Park, CA.

Jose, G. S. S., \& Christopher, C. S. (2018). Secure cloud data storage approach in e-learning systems. Cluster Computing, 1-6.

Koohang, Alex., Riley L, Smith, T. 2009. "E-Learning and Constructivism: From Theory to Application Interdisciplinary". Journal of E-Learning and Learning Objects. Vol. 5. From https://www.researchgate.net>320 6. Retrieved on $9^{\text {th }}$ June, 2020

LLC, Epignosis. 2014. "E-Learning Concepts, Trends, Application". San Fransisco: California. From https://www.talentlms.com/elearni ng/elearning-101-jan2014-

VI.1.pdf. Retrieved on $10^{\text {th }}$ June, 2020

M. GrandBastien, L. Oubahsi, and G.Claes. 2003. "A Process Oriented Approach for Modeling on Line Learning Environments." In Proc. 11th Int. Conf. Artif. 
Intell.educ.

Sydney,NSW,

Australia. Pp.140-152.

Marck, J.R. 2002. Book Review: ELearning Strategies for Delivering Knowledge in Digital Age. Internet and Higher Education, 5, 185-188. From https: onlinelibrary.wiley.com.

Retrieved on $10^{\text {th }}$ June, 2020

Morton CE, Saleh SN, Smith SF, Hemani A, Ameen A, Bennie TD. 2016. Blended Learning: How Can We Optimise Undergraduate Student Engagement? BMC Med Educ.16:195.

Parry D, Larsen C, Marwood C, Walsh C. 2007. "Realising E-Learning Matters in a Bioscience Cohort". Bioscience Educ. 10:1-10.

Rabiman R., Nurtanto M., Kholifah N. 2020. Design and Development E-Learning System by Learning Management System (LMS) in Vocational Education. International Journal of Scientific \& Technology Research Volume 9, Issue 01, January 2020.

Rannastu-Avalos, M., and Siiman, L. A. 2020. "Challenges for Distance Learning and Online Collaboration in the Time of Covid-19: Interviews with Science Teachers," Lecture Notes in Computer Science (Including Subseries Lecture Notes in Artificial Intelligence and Lecture Notes in Bioinformatics), pp. 128142. (https://doi.org/10.1007/9783-030-58157-2_9).

Ruiz JG, Mintzer MJ, Leipzig RM. 2006. The Impact of E-Learning in Medical Education. Acad Med. 207-12

Smedley, J.K. 2010. Modeling the Impact of Knowledge Management using Technology. Or Insight (2010) 23, 233-250. From https://www.researchgate.net $>220$

4 Retrieved on $10^{\text {th }}$ June, 2020

Wan Hassan, W. A. S., Ariffin, A., Ahmad, F., Sharberi, S. N. M., Nor Azizi, M. I., and Zulkiflee, S.N. 2020. "Covid-19 Pandemic: Langkawi Vocational College Student Challenge in Using Google Classroom for Teaching and Learning (T\&amp;L), International

Wentling, T.L, et al., 2000. E-Learninga Review of Literature. Knowledge and Learning System Group NCSA.9.1-73. From https://www.researchgate.net/publ ication/331938876 . Retrieved on $10^{\text {th }}$ June, 2020

Zhang, D., Zhou, L., Brlggs, R \& Numaker, J. 2006. Instructional Video in E-Learning: Assessing the Impact of Interactive Video on Learning Effectiveness. Information \& Managemnt. Vol $43 \quad$ (1), 15-27. From https://www.scincedirect.com Retrieved on $10^{\text {th }}$ June, 2020 